\section{Biotechnology and Brown Shirts}

SIR - Scientists should find it chilling that "[1]ast year, all 15 small-scale field trials conducted by universities and research institutes in Germany were partially or fully destroyed by activists, even though most of those experiments were studying the environmental safety of growing genetically manipulated plants in normal agricultural environments" (Nature 380, 94; 1996).

It recalls Germany in the 1930s, when the Third Reich vilified and persecuted the practitioners of what the regime called Entartete Kunst, "degenerate art". These subversives included Marc Chagall, Emil Nolde, Max Beckmann, Henri Matisse, Edvard Munch and Pablo Picasso.

Now we have a kind of Entartete Forschung, "degenerate research". The German government is not culpable, except indirectly by neglecting to protect the personal safety and property of plant scientists against assaults by anti-biotechnology activists.

But the vandals are abetted by government ambivalence and policies that equate innovation with risk. There is an obvious solution - one that has been purposefully ignored by policy-makers in both the European Union (EU) and Germany: simply apply scientific and risk-based regulatory policies to the testing of transgenic plants.
As Nature said in a leading article in 1992 (356, 1-2), a broad scientific consensus holds that "the same physical and biological laws govern the response of organisms modified by modern molecular and cellular methods and those produced by classical methods.... [Therefore] no conceptual distinction exists between genetic modification of plants and microorganisms by classical methods or by molecular techniques that modify DNA and transfer genes."

Disregarding the scientific consensus, current EU and German regulation requires extensive case-by-case government environmental assessments for proposed field testing with recombinant-DNA-manipulated plants. By contrast, phenotypically similar or identical plants are usually not subject to government scrutiny or requirements (or publicity) at all. And that applies even to the many new plant varieties that result from 'wide crosses', hybridizations in which genes have been moved from one species or genus to another - 'transgenic' plants by any reasonable scientific definition.

If recombinant-DNA-manipulated plants were treated like other new varieties, their testing would not need government review, special warning signs or public announcements. There would be no way for the thugs to target and disrupt field research that they have decided are Entartete Forschung.

There is an important lesson here: the problem would have been avoided entirely if public policy had been crafted intelligently in the first place.

\section{Henry I. Miller}

Hoover Institution \& Institute

for International Studies,

Stanford University,

Stanford, California 94305-6010, USA

\section{Mild conversion?}

SIR - The gentler tone of John Maddox (Nature 378, 435-437; 1995) would almost seem to represent a mild conversion. His appeal to religious scientists to help his unloved colleagues is quite touching.

If there really is serious distrust of science in our society, there are two matters on which we might meditate a little. The first is rather prosaic, but causes persistent annoyance. Listening to Wolpert or Dawkins, for instance, one is aware that some of the senior practitioners consider themselves, as scientists, to be in a very special category of human being. Rationality is their special preserve; and those outside science are assumed to be incapable of following their levels of logic. To me, this is both sad and nonsensical. By and large, I would say that scientists deal with the easier problems. In

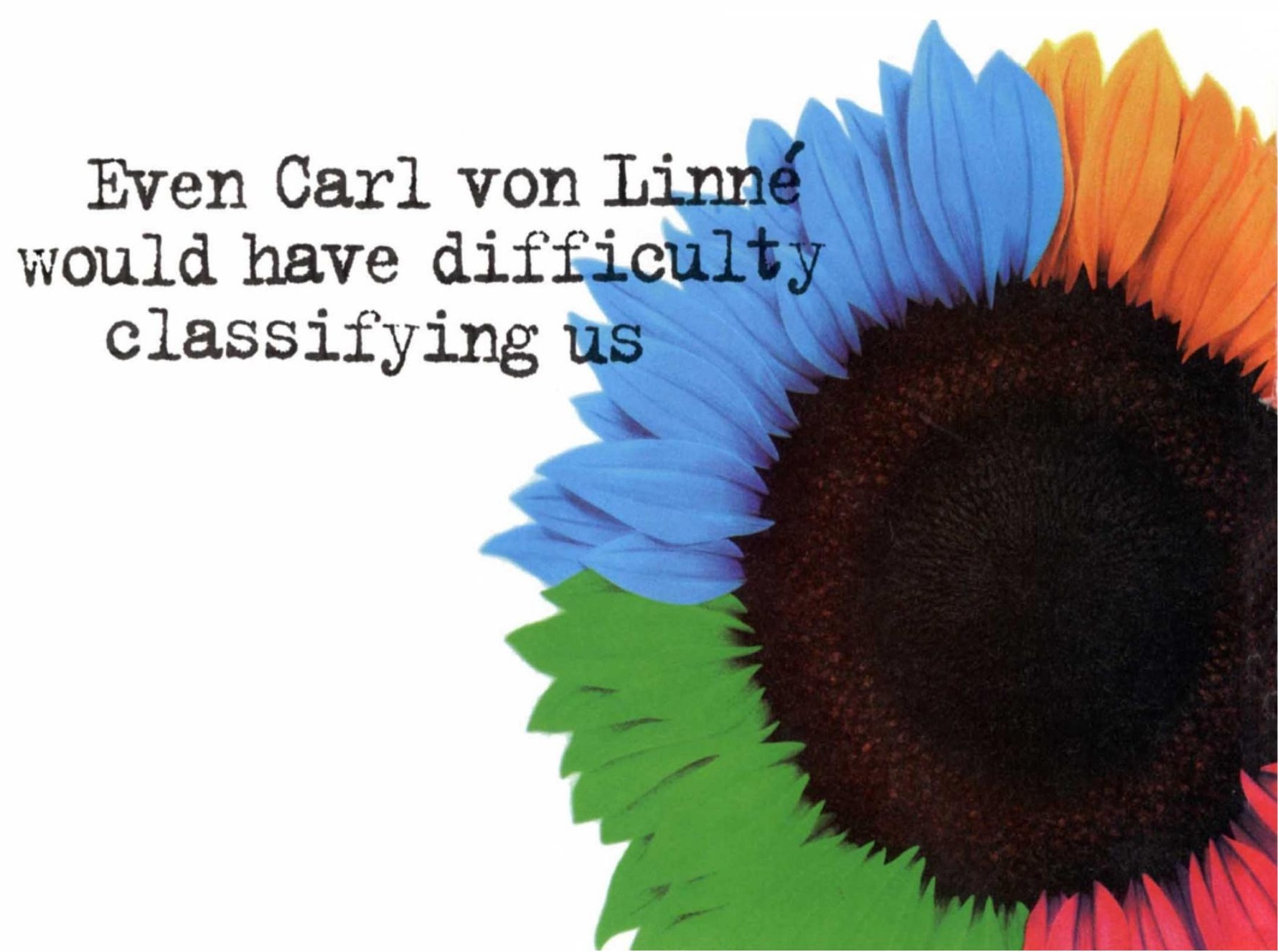


fact, they deliberately select those problems that may lead to some specific solution. Others - historians, teachers, nurses, lawyers, architects, musicians, or whatever - work to equally demanding disciplines, and do not have the luxury of selecting easier options. And they are generally sensible enough to see their work as part of the overall culture. I see no need for any special status for scientific activity.

The more serious point I would make is that this century will be seen by future historians, not as Maddox would like us to view it, but as quite the most barbaric in all history. The two world wars, in which all sides indulged in indiscriminate slaughter, had their origins to some extent in scientific notions - 'survival of the fittest' and genetic purity. Also, there was never the slightest difficulty in recruiting leading scientists to design lethal weapons. Given money and security, scientists, like most other people, will do what is asked of them. There are very few exceptions.

With the knowledge and power we now possess, we need so much more than the abstract, impersonal logic of science. Those who wish to make an alternative religion of Darwinism and reductionism, and encourage belief in the pointlessness of existence, seem to have learnt nothing from the history of this century.

Maddox's final quixotic comment there are still molecular biologists who go to church - reveals much. To those of us not wedded to Darwinian dogma, one might just as well say that there are scientists who still read Plato. We may have cells and DNA that have much in common with the animal world. But in our mentality - which has apparently arisen spontaneously in the last few moments of evolutionary time - we are light years ahead of any other organism. Externally, we have transformed the Earth, creating cities and civilizations; internally, we compose symphonies and formulate predictive mathematical theories. At our best, we think seriously about purpose and meaning, and try to assess the human and social consequences of our work. In this, science provides no guidance, and we each have to find our own path. Religious thought provides one option.

John Evans

81 Cherry Hinton Road,

Cambridge CB1 $4 B S$, UK

\section{Smoke them out}

SIR - Precious research funds are being spent on attempts to identify means of deterring people from smoking. I have a suggestion that might yield economies. In Britain at least, young people, especially women, continue to smoke despite warnings by public health authorities of the dangers. The fault may lie in the messages that adorn cigarette packages and advertising hoardings. "Harm your baby" or "Cause fatal diseases" are anodyne if not challenging to young people. They see smoking as fashionable, romantic, anarchic and exciting: all the supermodels smoke, as do Hugh Grant and Elizabeth Hurley, futures traders and Porsche drivers ${ }^{1}$.

My suggestion is this. Smoking is associated with urinary incontinence in women ${ }^{2,3}$. Moreover, one may assume that the association is causal because transdermal oestrogen is effective in the treatment of mild to moderate stress urinary incontinence in postmenopausal women ${ }^{4}$, and cigarette smoking is anti-oestrogenic ${ }^{5}$.

Cigarette packets should therefore carry the message "Cigarettes cause urinary incontinence". Young people may be half in love with easeful death, but easeful incontinence is a different matter. Once smoking becomes associated with incontinence pads, it will become less fashionable.

\section{William H. James}

Department of Genetics and Biometry, University College London,

Wolfson House,

\section{Stephenson Way,}

London NW1 2HE, UK

1. Coren, G. The Times, 6 December 1995.

2. Tampakoudis, P. et al. Eur. J. obst. Gyn. 63, 27 (1995).

3. Bump, R. C. \& McClish, D. K. Am. J. obstet. Gynec. 167, 1213 (1992).

4. Mäkinen, J. I . et al. Maturitas 22, 233 (1995).

5. Michnovicz, J. J. Steroids 52, 69 (1988). professor, lecturer and a resident of the Swedish university city of Uppsala (pronounced OOP-SA-LA). A consummate classifier, Linné systematized the plant, animal and mineral kingdoms as well as drew up a treatise on the diseases known in his day.

If Linné were alive today, he'd be proud of the vast number of diverse and important scientific fields researchers are involved in. Our job is to help life scientists find solutions by getting involved in their activities. We're Pharmacia Biotech-also from Uppsala.

The diversity of our involvement makes us a little tricky to classify at times. After all, our specialists work with such disciplines as (get
PCR-related areas, cDNA synthesis and cloning, vectors, nucleic acid electrophoresis, hybridization, sequencing, gene expression, restriction enzymes, modifying enzymes, nucleotides, oligonucleotides, polynucleotides, oligonucleotide synthesis, chromatography media, reagents, BioProcess chromatography, electrophoresis systems, electrophoresis media and spectrophotometry. As you can see, our company works with more than just one scientific discipline.

\section{Do you?}

If so, give us a call: I (800) 526-3593 in the USA; +81 334926949 in Japan; or +4618 165000 in Europe and the rest of the world. Or visit us on the Internet: http://www. biotech.pharmacia.se.

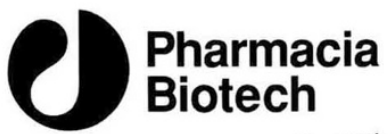

Uppsala. Sweden. (And the rest of the world) 